\title{
Production and Comparison of Indigenous and Commercial Baker's Yeasts
}

\author{
Nafisa Azmuda, Nasrin Jahan and Anisur Rahman Khan* \\ Department of Microbiology, University of Dhaka, Dhaka 1000, Bangladesh
}

[Received 23 February 2006; Accepted 07 October 2006]

\begin{abstract}
A comparative investigation on the characteristics, production and leavening action of two indigenous (isolate FR-1 and DP-4) and three commercial baker's yeasts (Saccharomyces cerevisiae strain FT, FP-1 and FP-2) was carried out in laboratory scale. The indigenous baker's yeasts, FR-1 and DP-4, were isolated from fermented rice and decomposed pineapple and they were presumptively identified as Saccharomyces cerevisiae and Saccharomyces species respectively. Among these five yeast isolates, FR-1, FT, FP-1 and FP-2 were found similar in morphological and cultural characteristics. The effect of physicochemical properties on the growth and production of cell mass was studied. The maximum cell mass was found after $36 \mathrm{~h}$ of incubation during growth in MYGP and MYMP media containing $1.5 \%$ glucose at $30^{\circ} \mathrm{C}$ and $\mathrm{pH} 5.0$. The maximum cell mass was produced by DP-4, followed by FP-2, FR-1, FT and FP-1. The effect of different bread ingredients on leavening was also investigated and it was found that oil, butter, egg and milk influenced the leavening action by these yeasts. The pathogenicity test of FR-1 and DP-4 on animal models (rabbits) exhibited no abnormalities in the experimental animals. The indigenous isolates, FR-1 and DP-4, seemed potential as candidates for bread making.
\end{abstract}

Keywords: Baker's yeast, Saccharomyces cerevisiae, Physicochemical parameters, Cell mass, Leavening action

\section{Introduction}

Baker's yeast is used to leaven bread throughout the world and it is the type of yeast that people are most familiar with ${ }^{1-2}$. Commercial baker's yeasts (Saccharomyces cerevisiae) are mostly used for the fermentation of modern bread making ${ }^{3}$. These yeast products contain almost $5 \%$ contaminating lactic bacteria and these bacteria play an important role in the production of flavour quality breads ${ }^{4-5}$. Today, in this first decade of the $21^{\text {st }}$ century, baker's yeast is produced in worldwide quantities of 2.3 million tons per annum ${ }^{6}$.

Yeasts perform three main functions in a panary fermentation, as it produces carbon dioxide in sufficient quantities to inflate the dough and produce a light spongy texture that will result in a palatable bread when correctly baked, cause 'maturing' or 'ripening' of the bread and produces a complex mixture of chemical compounds that contribute to the flavour of the bread ${ }^{7}$. In addition to producing carbon dioxide, the lactic acid-forming bacteria also produce acids. The acids contribute to the flavour of the finished bread and enhance the storage properties ${ }^{8}$.

Bangladesh is a developing country and a major part of the urban peoples is changing their food habit because of the fast food culture of the western world. One of the basic ingredients of these fast foods is bread. As a result the use of commercial baker's yeast is increasing day-by-day. A considerable amount of foreign currency is spent to meet the annual demand of our bakery industries. So, it is important to find out a good quality baker's yeast, which would fulfil this demand. The objective of this study was to make a comparative evaluation among the three commercial baker's yeasts and two indigenous yeast isolates to find out suitable indigenous yeast that would fulfil all desirable criteria of baker's yeast.

\section{Materials and Methods}

Raw materials and substrates used

Molasses (40\%), the by-product of sugar cane industries, obtained from the local markets of Dhaka city, and glucose, sucrose, lactose, etc. were used as carbon sources in the comparative growth studies of the yeasts. Good quality of flour, sugar, salt, egg, milk, butter and soybean oil, etc. used were collected from markets of Dhaka city.

\section{Media and microorganisms}

Different strains of commercial baker's yeasts (Saccharomyces cerevisiae); named as Ferment (FT) and Fermipan (FP-1 and FP-2) produced by Akmaya (Turkey) and DSM bakery ingredients (Holland) respectively were used for the investigation. The indigenous yeasts were isolated from various decomposed fruits and fruit juices as apple, banana peel, grapes, mango, pineapple, sugarcane juice and fermented rice in the laboratory. Among them, indigenous and three commercial yeasts were selected for investigation. The two indigenous isolates FR-1 and DP-4 were isolated from fermented rice and decomposed pineapple

*Corresponding author:

Dr. Anisur Rahman Khan, Professor \& Chairman, Department of Microbiology, University of Dhaka, Dhaka 1000, Bangladesh

Tel (Office): (02) 9661900-73/7730, 7740; Tel (Home): (02) 9571211; Cell: 01199 156618; Fax: +880 (02) 8615583; E-mail: anis37@yahoo.com 
respectively. The liquid MYGP medium ${ }^{9-10}$ (containing malt extract $3.0 \mathrm{~g} / \mathrm{l}$, yeast extract $3.0 \mathrm{~g} / \mathrm{l}$, peptone $5.0 \mathrm{~g} / \mathrm{l}$ and glucose $10.0 \mathrm{~g} / \mathrm{l}$, $\mathrm{pH}$ adjusted to 5.0) was used for the cultivation and production of yeast isolates under various conditions. MYMP (malt extract $3.0 \mathrm{~g} / \mathrm{l}$, yeast extract $3.0 \mathrm{~g} / \mathrm{l}$, peptone $5.0 \mathrm{~g} / \mathrm{l}$ and molasses) broth medium was used for cell mass production and prepared with of molasses instead of glucose.

\section{Characterization of the yeasts}

The size, shape and reproducing system of the yeasts were observed under a bright-field microscope. Yeast colonies grown on MYGP agar at $30^{\circ} \mathrm{C}$ for $30-48 \mathrm{~h}$ were studied for size, shape, form, margin, elevation, colour, etc. The growth characteristics (pellicle, turbid, flocculent, etc.) of the yeast strains in MYGP liquid medium were also studied.

\section{Growth measurement}

Biomass was measured by dry weight method ${ }^{11}$.

\section{Reducing sugar assay}

Reducing sugar present in the liquid culture was determined by the dinitrosalicylic acid (DNS) method ${ }^{12}$ with glucose as standard.

\section{Production of the yeasts under different conditions}

The effect of different parameters (such as inoculum size, incubation period, agitation, temperature, $\mathrm{pH}$ of the medium, different carbon substrates and substrate concentrations) on growth was determined by growing the yeasts in liquid MYGP medium. The cell mass, cell number and the quantity of reducing sugar were measured.

\section{Leavening action}

After growth of the yeasts in liquid medium, the culture was centrifuged at 7000x $g$ for $10 \mathrm{~min}$. The cell mass deposit was then washed with one-fourth diluted cultural broth and was collected into sterile Falcon tubes. Dough was prepared by mixing wheat flour (50 g), yeast cell (1 g), sugar (2 g), salt (0.5 g), milk (10 ml), soybean oil (1 ml), butter $(1 \mathrm{~g})$, egg (1 g) and water (40 $\mathrm{ml})$ in a $250-\mathrm{ml}$ beaker. The dough was incubated for 2-3 $\mathrm{h}$ at $30^{\circ} \mathrm{C}$ for fermentation and was baked at $105^{\circ} \mathrm{C}$ for $1.5 \mathrm{~h}$ for bread preparation. A negative control was taken, which was made with the same ingredients described above except the yeast cells. To determine the effect of different ingredients on the increase of dough volume, different combinations of ingredients were added at different time. The ingredients used were flour, sugar, salt, soybean oil, milk, egg, butter and water. Due to the metabolic action of yeast in the dough, its volume was increased. The height of the dough was measured from the graduated surface of the beaker before and after fermentation and the net increased volume was calculated ${ }^{13}$.

\section{Animal test}

Prepared bread (20 g) using two indigenous yeast isolates was fed to two rabbits after starvation for $24 \mathrm{~h}$. The rabbits were observed for a week whether they exhibit any abnormalities or not.

\section{Results and Discussion}

An extensive screening procedure had been performed to find suitable baker's yeasts from various sources. Initially, 20 yeast isolates were obtained, purified and selected for evaluation of the baking property. On the basis of cell mass production and leavening action two yeast isolates were selected for final study and these were identified as Saccharomyces cerevisiae (FR-1) and Saccharomyces species (DP-4). The microscopic and cultural characteristics of the yeasts were investigated. FR-1, FT, FP-1 and FP-2 resembled quite similar characteristics showing moderate, circular, opaque and off-white colonies with entire margins and convex elevations, while the colonies of DP-4 were large and flat on agar media. FR-1, FT, FP-1 and FP-2 gave sediment growth in liquid media but DP-4 gave pellicle. The cells of DP-4 were small and both ovoid and spherical in shape, whereas the cells of the other four isolates were large and ovoid in shape.

Various nutritional and environmental conditions usually affect the growth and leavening action of yeast strains. Cell mass production is affected by initial inoculum concentration. Different sizes of five yeast inocula ranging from $10^{7}$ to $10^{9}$ cells $/ \mathrm{ml}$ were added in $100 \mathrm{ml}$ MYGP broth media in $500-\mathrm{ml}$ conical flask at $30^{\circ} \mathrm{C}$ for $24 \mathrm{~h}$ for cultivation. In this study, we found that the production of cell mass was increased with increasing inoculum size, and the maximum cell mass was produced by the yeast DP-4 (6.46 g/l), followed by FP-2 (5.51 g/l), FR-1 (5.45 g/l), FT (5.37 g/l) and FP-1 $(5.05 \mathrm{~g} / \mathrm{l})$ with initial inoculum size of $5.0 \times 10^{8}$ cells $/ \mathrm{ml}$. The amount of residual reducing sugar was also low with this inoculum size. The amount of cell mass production was decreased after further increase of inoculum size.

The yeasts produced maximum amount of cell mass and lowest amount of residual reducing sugar after $36 \mathrm{~h}$ of incubation. The highest amount of cell mass was produced by DP-4 (6.76 g/l), followed by FP-2 (5.71 g/l), FR-1 (5.67 g/l), FT (5.65 g/l) and FP-1 $(5.45 \mathrm{~g} / \mathrm{l})$. After subsequent incubation period there was no significant increase in cell number or cell mass probably due to the shortage of nutrients, accumulation of growth inhibitory byproducts or deviation of the optimum $\mathrm{pH}$ of the medium.

Aeration and agitation have great influence on the production of cell mass. The maximum amount of cell mass was produced by DP-4, which was followed by FP-2, FR-1, FT and FP-2 when they were grown in rotary shaker incubator (140 rpm) than under static condition. Temperature is one of the major environmental factors for growth of yeasts. Each of the five yeasts were inoculated in MYGP broth medium and incubated at four different temperatures $\left(25^{\circ}, 28^{\circ}, 30^{\circ}\right.$ and $\left.35^{\circ} \mathrm{C}\right)$ for $36 \mathrm{~h}$ at $140 \mathrm{rpm}$ and the optimum temperature found was $30^{\circ} \mathrm{C}$. The effect of temperature on growth of the yeasts is shown on Figure 1. DP-4 produced highest amount of cell mass ( $6.52 \mathrm{~g} / \mathrm{l})$, followed by FR-1 (5.57 g/l), FP-2 (5.32 g/l), FT (5.27 g/l) and FP-1 (5.00 g/l). The result was consistent with the findings of other investigators ${ }^{13-14}$ who obtained maximum cell mass production in the range of $20^{\circ}$ to $30^{\circ} \mathrm{C}$. The amount of residual reducing sugar was low at this temperature. 
Cell mass vs. temperature

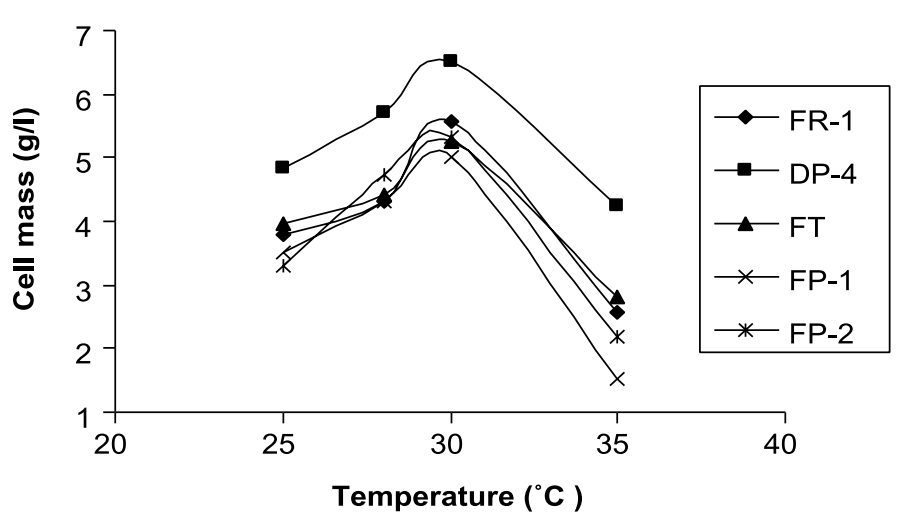

Figure 1. Effect of temperature on the growth and production of the yeasts. FR-1 and DP-4 = Indigeneous yeasts; FT, FP-1 and FP-2 = Commercial yeasts

The $\mathrm{pH}$ is another factor and the variation (4.0 to 5.5) of which markedly influenced the growth and production of cell mass by the yeasts. The baker's yeasts can be grown at $\mathrm{pH}$ levels ranging from 3.6 to 6.0 with optimum levels between 4.5 and $6.0^{8}$. The amount of reducing sugar was also low. The effect of $\mathrm{pH}$ on growth and production of the yeasts is shown on Figure 2. The yeast strain DP-4 produced the highest amount of cell mass (6.03 g/l), followed by FP-2 (5.25 g/l), FR-1 (5.20 g/l), FT (5.11 g/l) and FP-1 (5.05 g/l), at pH 5.0.

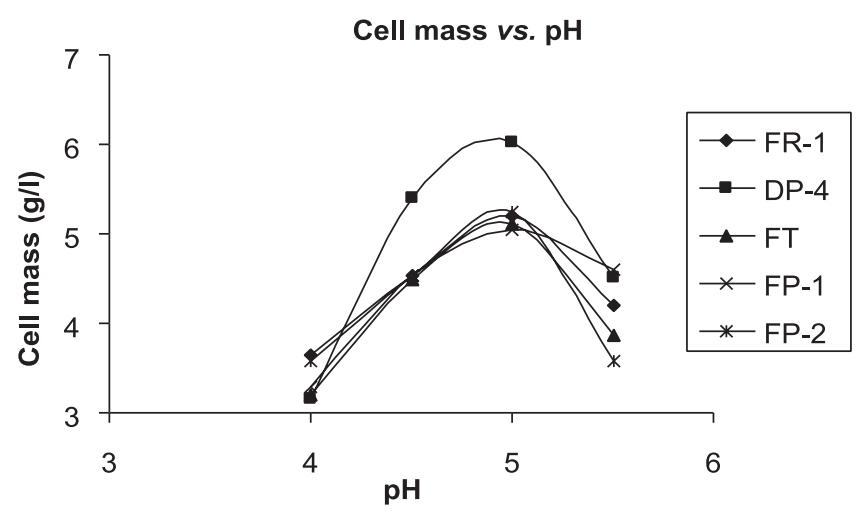

Figure 2. Effect of $\mathrm{pH}$ on the growth and production of the yeasts. FR-1 and DP-4 = Indigeneous yeasts; FT, FP-1 and FP-2 = Commercial yeasts

The principal carbon and energy source for the production of baker's yeast is cane or beet molasses ${ }^{8}$. In this study, yeasts were grown on $1 \%$ glucose, sucrose, lactose and molasses. Maximum cell mass was produced in presence of sucrose by all the isolates. Comparatively the indigenous yeast FR-1 produced almost same amount of cell mass with molasses as with sucrose and DP-4 produced almost same amount of cell mass with glucose and molasses. In another investigation, it was found that the production of cell mass was highest in presence of sucrose, followed by glucose, molasses and lactose by three commercial baker's yeast strains ${ }^{15}$. To determine the best substrate concentration for the growth of the yeasts, various concentrations
(1.0-2.5\%) of glucose and molasses were added in the liquid media. It was found that the yeast isolates produced the highest amount of cell mass in presence of $1.5 \%$ sugar concentration, and the amounts of cell mass produced by all of the five yeast isolates were higher with molasses than with glucose.

Determination of the optimum temperature and $\mathrm{pH}$ for growth and cell mass production for the yeasts were carried in MYMP medium containing $1.5 \%$ sugar. It was found that the optimum temperature and $\mathrm{pH}$ were $30^{\circ} \mathrm{C}$ and 5.0 respectively for all the five yeasts. In another study, it was found that the production of cell mass by three commercial baker's yeasts was highest at $30^{\circ} \mathrm{C}, \mathrm{pH}$ 5.0 at $200 \mathrm{rpm}$ after $30 \mathrm{~h}$ incubation in MYGP medium containing $2 \%$ glucose with an inoculum size of $5.0 \times 10^{4}$ cells $/ \mathrm{ml}^{15}$.

The effect of bread ingredients on leavening actions of the yeasts was also studied. Dough was prepared with 1 g yeast cell (2\% inoculum) and a variety of ingredients such as flour, sugar, salt, egg, milk, soybean oil, butter, etc. To find out the effect of each ingredient the dough was prepared with different combinations of ingredients and compared with a negative control containing no yeast cells. The volume of the control dough was not increase after incubation, while the volume of the dough containing yeast cells was increased. The percentage of the increased dough volume by the five yeast isolates is shown in Table 1. Interestingly, the indigenous isolate DP-4 that gave maximum cell yield was not the superior in dough volume increase, whereas another indigenous yeast FR-1 showed excellent performance in increasing the dough volume within short period of time that was comparable to the commercial strains. It was also observed that the mixture of butter, egg, milk and oil together had positive influence on fermentation time but its absence was favourable for the overall fermentation capacity by the yeast strains. DP-4 produced highest dough volume only when other ingredients besides flour, sugar and salt were used, whereas FR-1 gave almost the same result with each ingredient and which was comparable to the commercial strains, FP-1 and FP-2. The indigenous yeasts (FR-1 and DP-4) produced acceptable flavour during baking as like as the commercial yeasts. Animal tests were carried out with the bread prepared by using the two indigenous yeasts and no abnormality was found in the rabbit subjects.

From the present study it could be concluded that the indigenous yeast isolates FR-1 and DP-4 seemed to meet the desired characteristics of baker's yeast. The isolates showed better results with respect to the production and leavening action compared with that of commercial baker's yeasts. Further studies on the physicochemical properties and molecular biology of these indigenous yeasts could be carried out in order to improve their performance in bread making. 
Table 1. Influence of dough ingredients on dough volume by selected yeasts

\begin{tabular}{|c|c|c|c|}
\hline Ingredients of dough & Isolate & $\begin{array}{c}\text { Increased } \\
\text { dough } \\
\text { volume (\%) }\end{array}$ & $\begin{array}{l}\text { Time } \\
\text { required } \\
\text { (h) }\end{array}$ \\
\hline \multirow{6}{*}{$\begin{array}{l}\text { Flour, sugar, } \\
\text { salt \& water }\end{array}$} & Negative control & 0 & - \\
\hline & FR-1 & 116 & 3 \\
\hline & DP-4 & 184 & 10 \\
\hline & FT & 152 & 4 \\
\hline & FP-1 & 156 & 6 \\
\hline & FP-2 & 148 & 2 \\
\hline \multirow{6}{*}{$\begin{array}{l}\text { Flour, sugar, salt, } \\
\text { soybean oil \& } \\
\text { water }\end{array}$} & Negative control & 0 & - \\
\hline & FR-1 & 120 & 4 \\
\hline & DP-4 & 104 & 9 \\
\hline & FT & 192 & 4 \\
\hline & FP-1 & 172 & 5 \\
\hline & FP-2 & 144 & 4 \\
\hline \multirow{6}{*}{$\begin{array}{l}\text { Flour, sugar, salt, } \\
\text { milk \& water }\end{array}$} & Negative control & 0 & - \\
\hline & FR-1 & 140 & 4 \\
\hline & DP-4 & 104 & 9 \\
\hline & FT & 100 & 4 \\
\hline & FP-1 & 152 & 4 \\
\hline & FP-2 & 144 & 4 \\
\hline \multirow{6}{*}{$\begin{array}{l}\text { Flour, sugar, salt, } \\
\text { soybean oil, } \\
\text { milk \& water }\end{array}$} & Negative control & 0 & - \\
\hline & FR-1 & 148 & 5 \\
\hline & DP-4 & 144 & 9 \\
\hline & FT & 132 & 2 \\
\hline & FP-1 & 168 & 2 \\
\hline & FP-2 & 136 & 3 \\
\hline \multirow{6}{*}{$\begin{array}{l}\text { Flour, sugar, salt, } \\
\text { soybean oil, milk, } \\
\text { egg, butter \& } \\
\text { water }\end{array}$} & Negative control & 0 & 16 \\
\hline & FR-1 & 108 & 2 \\
\hline & DP-4 & 100 & 7 \\
\hline & FT & 104 & 2 \\
\hline & FP-1 & 120 & 4 \\
\hline & FP-2 & 152 & 2 \\
\hline \multirow{6}{*}{$\begin{array}{l}\text { Flour, sugar, salt, } \\
\text { soybean oil, egg, } \\
\text { butter \& water }\end{array}$} & Negative control & 0 & - \\
\hline & FR-1 & 152 & 3 \\
\hline & DP-4 & 144 & 9 \\
\hline & FT & 160 & 3 \\
\hline & FP-1 & 164 & 3 \\
\hline & FP-2 & 140 & 2 \\
\hline
\end{tabular}

\section{References}

1. Chen SL \& Chiger M. 1985. Production of baker's yeast. In Comprehensive Biotechnology (Moo-Young M ed), Vol 3, pp 429456. Pergamon Press Ltd, New York.

2. Barnett JA, Payne RW \& Yarrow D. 1983. In Yeasts Characteristics and Identification, pp 1-35. Cambridge University Press, Cambridge.

3. Lyall N. 1970. Studies on the ecology of yeasts. Baking Ind J. 3: 4852.

4. Kishberg R. 1972. The microbe as a source of food. Ann Rev Microbiol. 26: 427-466.

5. Sugihara TF. 1985. Microbiology of bread making. In Microbiology of Fermented Foods (Wood BJB ed), Vol 1, pp 249-250. Elsevier Applied Science Publishers, London.

6. Blakely R. 2004. Making dough from bread. Times Online. July 22.

7. Oura E, Suomalainen H \& Viskari R. 1982. Bread making. In Economic Microbiology (Rose AH ed), Vol 7, pp 112-113. Academic Press Inc Ltd, London.

8. Reed G. 1982. Production of baker's yeast. In Prescott and Dunn's Industrial Microbiology (Reed G ed), $4^{\text {th }}$ edn, pp 593-627. AVI Publishing Company Inc, New York.

9. Mot RD, Dijk KV, Donkers A \& Verachtert H. 1985. Potentialities and limitations of direct alcoholic fermentation of starchy materials with amylolytic yeasts. Appl Microbiol. 22: 222-226.

10. Perkins JJ. 1976. In Principles and Methods of Sterilization in Health Science, pp. 286-292. Charles C Thomas Publishers, Springfield III.

11. Pelczar MJ, Chan ECS \& Krieg NR. 1986. Microbiology, $5^{\text {th }}$ edn, pp 125-129. McGraw Hill Book Co Inc, San Francisco.

12. Miller GL. 1959. Use of dinitrosalicylic acid for determination of reducing sugar. Anal Chem. 31: 426-428.

13. Parveen M. 1991. Isolation, characterization and evaluation of indigenous baker's yeast. MSc Thesis, pp 20-59. Department of Microbiology, University of Dhaka, Dhaka.

14. Eroshin VA, Utkin IS, Ladynichev SV, Samolov VV, Kuyshnnikov VD \& Skoyabin GK. 1976. Influence of $\mathrm{pH}$ and temperature on the substrate yield coefficient of yeast growth in a chemostat. Biotechnol Bioeng. 18: 289-295.

15. Nahar MF. 2004. Baker's yeast: Characterization, production and leavening action. BSc Research Project Report, pp 37-40. Department of Microbiology, University of Dhaka, Dhaka. 